\title{
Erratum to: Additive Manufacturing in the Minerals, Metals, and Materials Community: Past, Present, and Exciting Future
}

\author{
EDWARD D. HERDERICK ${ }^{1,2}$ \\ 1.-GE Corporate Supply Chain and Operations, Cincinnati, OH, USA. 2.-e-mail: Edward. \\ herderick@ge.com
}

\section{Erratum to: JOM}

DOI: 10.1007/s11837-015-1799-4

Due to an error during production, the author's name appeared incorrectly in the original PDF version of this article. It has since been updated.

The online version of the original article can be found under doi:10.1007/ s11837-015-1799-4. 